\title{
Academic Anxiety among Adolescents in Relation to Socio-Emotional School Climate
}

\author{
Sona Thakur ${ }^{1}$, Ajay Kumar ${ }^{2}$ \\ Assistant Professor, Partap College of Education, Ludhiana
}

\begin{abstract}
The present study aims at studying the levels of Academic Anxiety among Adolescents in relation to Socio-Emotional School Climate. For this purpose a sample is taken which is the representative of the population. The investigator has used Academic Anxiety Scale (A.A.S.) by Pal, Misra and Pandey (1985) and Socio-Emotional School Climate Inventory (S.E.S.C.I.) by Sinha and Bhargava (1998) to collect the data. Non-probability method of sampling was followed for selection of Ludhiana district out of 20 districts of the state. Then, using the probability method of sampling, 10 secondary schools of Ludhiana district and further, the adolescents from these schools were selected. In all, a sample of 200 secondary students was drawn from the different schools of Ludhiana district. The result of the study showed that there is a negative relationship between academic anxiety and socio-emotional school climate among adolescents of Ludhiana district. The result also shows that academic anxiety did not differ significantly with respect to gender but shows a significant difference with respect to demographic location.
\end{abstract}

Keywords: Academic Anxiety, Adolescents, Socio-Emotional School Climate, secondary schools

\section{Introduction}

Educational or academic anxiety is a kind of anxiety which relates to the imminent danger from the environment of the educational institutions together with teacher and certain subjects like Chemistry, Physics for numerical, Mathematics, and English to some extent for some north Indian states. It is a mental sensitivity of uneasiness or distress in response to school or college circumstances that is perceived negatively. Academic anxiety is totally not a bad thing. However, it is true that a high level of anxiety interferes with concentration and memory which are critical for day to day academic performance and success, however it is also true without any anxiety, majority of us would lack the enthusiasm and motivation to study for exams, do everyday homework or write any research papers. A modest amount of anxiety actually helps academic performance by creating morale and motivation. Academic anxiety is a common issue that students cannot ignore if they want to achieve academic success in school. If academic anxiety is not properly addressed, it can have many serious, severe and long lasting consequences such as causing a student to start hating a subject or a teacher, procrastinate, tell lies to parents, perform poorly on school work, absent classes to pursue activities that interest him and withdraw from socializing with peers or friends and may recoil into his own cocoon and drop school. Reddy (1989) conducted research to find out the adjustment and problem areas of many adolescents in the school and the results showed that most of the problems concentrated on academic anxiety followed by anxiety regarding their future. Verma and Gupta (1990) explored the causes of basic academic pressure burdening the school going adolescents. Results revealed that academic stress was caused due to examination system, burden of homework and attitudes of parents and teachers. Ahmad (2012) in a study of the impact of socio-emotional school environment on the academic achievement of teenager boys revealed that there is a significant relation between academic achievement and socio-emotional school environment of govt. aided higher secondary teenager boys. Thus, socioemotional school climate and facilities play a significant role in academic achievement of the students. These include school's co-curricular activities provided for all round development of the child, attitude of teachers towards students, methods of teaching, curriculum, peer group influence, academic enrichment and special education for the children. A positive socio-emotional school climate is essential to promote good student achievement and it is important to foster positive student attitudes. A favorable socio-emotional school climate provides a framework within which students, teachers, administrators and parents function co-operatively and productively. The present study is conducted after the review of related literature. After reviewing the literature, it was found that despite best efforts by investigators could not find even a single study on academic anxiety of adolescents in relation to socioemotional school climate. It shows there is a research gap, this motivated the investigators to conduct the present research study and this study is a humble att empt to fill in this research gap. This study was conducted with the following objectives.

\section{Objectives of the Study}

1) To study the Academic Anxiety among Adolescents.

2) To study the Socio Emotional School Climate of Adolescents.

3) To find out the relationship between Academic Anxiety and Socio Emotional School Climate of Adolescents.

4) To compare the Academic Anxiety of adolescent boys and girls.

5) To compare the Academic Anxiety of Adolescents from urban and rural areas.

\section{Method}

\section{Sample}

Sample for the present study is inclusive of 200 adolescents of Ludhiana District. It consists of 100 boys and 100 girls students from urban and rural secondary schools of Ludhiana District. The sample was equally distributed between boys and girls students. The probability method of

\section{Volume 4 Issue 11, November 2015}




\section{International Journal of Science and Research (IJSR) ISSN (Online): 2319-7064}

Index Copernicus Value (2013): 6.14 | Impact Factor (2014): 5.611

sampling was used to select 10 secondary schools of Ludhiana district and further, the adolescents from these schools were selected.

\section{Measure}

In the present study, Academic Anxiety Scale (A.A.S.) by Pal, Misra and Pandey (1985) and Socio-Emotional School Climate Inventory (S.E.S.C.I.) by Sinha and Bhargava (1998) were employed by the investigator to collect the data.

\section{Procedure}

The study was designed to investigate the academic anxiety among adolescents in relation to SocioEmotional school climate. Descriptive survey method of investigation was employed for the present study. Prior to the administration of the Academic Anxiety scale and SocioEmotional School Climate Inventory for adolescents, the investigator sought the cooperation of the head of the secondary schools and students. First of all purpose of the test was clarified to the students and instruction given to them according to the manual and rapport established with them. The scale of Academic Anxiety was administered according to the manual and after getting the response sheet, Socio-Emotional School Climate Inventory for adolescents was also administered in the same way. Scoring was done with the help of scoring key.

\section{Analysis and Interpretation of the Results}

\section{Section -I Coefficient of Correlation}

Table 1: Coefficient of Correlation between Academic Anxiety and Socio-emotional School Climate of Adolescents $(\mathrm{N}=200)$

\begin{tabular}{|c|c|c|}
\hline Group & $\mathrm{N}$ & $\mathrm{r}$ \\
\hline Boys & 200 & $-0.79^{* *}$ \\
\hline Girls & 200 & $-0.93^{* *}$ \\
\hline Rural & 200 & $-0.60^{* *}$ \\
\hline Urban & 200 & $-0.85^{* *}$ \\
\hline Total & 200 & $-0.84^{* *}$ \\
\hline
\end{tabular}

It is evident from table 1 that the coefficient of the correlation between academic anxiety and socio-emotional school climate among adolescent boys of Ludhiana District is -0.79 which is negative and significant at both levels of significance. Further the coefficient of the correlation between academic anxiety and socio-emotional school climate among adolescent girls of Ludhiana District is -.93 which is also negative and significant at both levels of significance. Further the table 1 also shows that the coefficient of correlation between academic anxiety and socio-emotional school climate among rural adolescents is 0.60 which is also negative and significant at both levels of significance. The coefficient of correlation between academic anxiety and socio-emotional school climate among urban adolescents of Ludhiana district was calculated as 0.85 which is also negative and significant at both levels of significance. It is also evident from the table 1 that the coefficient of correlation between academic anxiety and social-emotional school climate among adolescents of Ludhiana district is -0.84 which is negative and significant at both levels of significance. This implies that there is a negative and significant relationship exists between academic anxiety and socio-emotional school climate among adolescents of Ludhiana district. The negative relationship between academic anxiety and socio-emotional school climate of adolescents indicate that the adolescents who have better perception of their socio-emotional school climate experience lesser academic anxiety. Many studies conducted by Tanzer (1990) found in earlier school climate research significant relations between school-level climate and both test anxiety and alienation; specifically, that high quality interaction among students and between students and teachers was related to the lowest levels of test anxiety and self-reported feelings of alienation. LaPointe, Legault, and Batiste (2005) found an increase in test anxiety in math after the transition to middle school, when the perceived level of teacher support decreases. This effect was especially strong among students identified as academically talented. School and classroom climates have consistently been found to be directly related to achievement measures of language, reading, and math, and have also been found to moderate the negative effects of children's disruptive behavior on academic achievement (Posner \& Rothbart, 1998). These studies also support the results present study.

\section{Section-II: Significance of difference}

Table 2: Significance of the Difference between Mean Scores of Academic Anxiety of Adolescent Boys and Girls

\begin{tabular}{|l|l|l|l|l|l|}
\multicolumn{1}{c}{$(\mathrm{N}=200)$} \\
\hline Group & $N$ & $M$ & S.D & SED & $t$-value \\
\hline Boys & 100 & 8.49 & 4.45 & .60 & 1.94 \\
Girls & 100 & 7.31 & 4.15 & & \\
& & & & & \\
Rural & 100 & 11.06 & 3.49 & .42 & $5.55^{*}$ \\
Urban & 100 & 4.74 & 2.32 & & \\
\hline
\end{tabular}

It is evident from the table 2 that the mean scores of adolescent boys and girls on the variable of academic anxiety are 8.49 and 7.31 respectively. The t-ratio was calculated as 1.94 which is non significant at .05 level of confidence. This reveals that no significant difference exists between adolescent boys and girls on the variable of academic anxiety. It is also revealing that the mean scores of rural and urban adolescents on the variable of academic anxiety are 11.06 and 4.74 respectively. The t-ratio was calculated as 5.55 which is significant at both levels of significance. This means that there is significant difference exists between rural and urban adolescents on the variable of academic anxiety. As the higher score on an academic anxiety scale indicates low level of academic anxiety, thus rural adolescents having a significantly higher mean score on an academic anxiety than urban adolescents indicate that urban adolescents experience significantly low level of academic anxiety than their rural counterparts. Many studies conducted by Bihari (2014) found that there is no significant difference between the overall mean scores of secondary school boys and girls and rural and urban students on their academic anxiety while significant difference was found between the mean scores of government and private secondary school students on their academic anxiety. Singh and Thukral (2009) in his study reported that there exists a negative and significant relationship between anxiety and achievement. Significant differences were observed between

\section{Volume 4 Issue 11, November 2015}




\section{International Journal of Science and Research (IJSR) \\ ISSN (Online): 2319-7064}

Index Copernicus Value (2013): 6.14 | Impact Factor (2014): 5.611

boys and girls, rural and urban students on the basis of their anxiety. Pramod (1996) concluded, with reference to Indian culture, that boys manifested more futuristic orientation than girls and therefore boys have more academic anxiety than girls. Contradictory results are also reported in a study by Trivedi \& Ojha (2005), where they found that boys had higher academic anxiety as compared to girls. Bhansali and Trivedi (2008) in his study found that there is a considerable amount of Academic Anxiety prevailed amongst the sample. It was seen that girls on the whole had more incidences and intensity of academic anxiety in comparison to boys. Tina and Annayat (2014) found that there exists no significant difference in academic anxiety of adolescent boys and girls having executive, agriculture, social and household as area of vocational interest. There exists no significant difference in academic anxiety of adolescent boys and girls having agriculture, fine arts and science as area of educational interest. These studies support the results present study.

\section{Conclusion}

The result of the study showed that there is a negative relationship between academic anxiety and socio-emotional school climate among adolescents of Ludhiana district.This indicates that the adolescents who have better perception of their socio-emotional school climate experience lesser academic anxiety.The result also shows that academic anxiety did not differ significantly with respect to gender, but shows a significant difference with respect to demographic location. As higher scores on an academic anxiety scale indicates a low level of academic anxiety, thus rural adolescents having a significantly higher mean score in academic anxiety than urban adolescents indicate that urban adolescents experience significantly low level of academic anxiety than their rural counterparts.

\section{References}

[1] Ahmad, S. (2012). Impact of Socio-Emotional School Environment on Academic Achievement of TeenagerBoys. International Journal of Scientific and Research Publications, Volume 2. Retrieved from http:www.ijsrp.org.

[2] Anand, S.P. (1989). Anxiety Level of adolescents. Bush, M.B. Fifth Survey of Education Research, Vol. 11 NCERT, New Delhi, 963.

[3] Bhansali, R. \& Trivedi, K. (2008). Is Academic Anxiety Gender Specific: A Comparative Study. Journal of Social Science, 17(1), 1-3.

[4] Bihari, S. (2014). Academic Anxiety among Secondary School Students with reference to Gender, Habitat and Types of School. International Journal of Education and Psychological Research,3,(4), 30-32.

[5] Ganguli, P.K. (1983). Anxiety and Academic Achievement. Journal of Education Research and Extention, 25(2), 94-104

[6] Garg, G. (2011). Academic Anxiety and life skills of secondary school children.Journal of Community Guidance and Research, 28,465-475.

[7] Kaur, Harmanjeet, (2005). Study of Anxiety among adolescents in relation to environmental deprivation. M.Ed Dissertation, Panjab University, Chandigarh.
[8] Kaur, A. (2013).Study of Academic stress of XI students in relation to school environment.Miracle of Teaching.13(1), 16-19.

[9] Lapointe, J. M., Legault, F., \& Batiste, S. J. (2005). Teacher interpersonal behavior and adolescents' motivation in mathematics: A comparison of learning disabled, average, and talented students. International Journal of Educational Research, 43(1-2), 39-54.

[10] Manjuvani, (1992). Influence of home and school Environment on Academic Anxiety status of children an unpublished. Ph.D. Thesis, Buch M.B., Fifth Survey of Educational Research, Vol. II, NCERT, New Delhi, 968.

[11] Mishra, R. \& Suryawanshi, K. (2010). A study of Academic Anxiety and stress towards rural urban students .Journal of Educational Research and Extention, 24(2),35-38.

[12] Ojha, V. (2005). Academic Anxiety in Relation to Sex Role Orientation of Early Adolescents Between Ages 13-15 Years. Unpublished M.Sc. Dissertation, Jodhpur: JNV University.

[13] Pramod, S. (1996). Future time perspectives, cognitive efficiency, achievement motivation, anxiety and academic performance among eleventh standard boys and girls. Indian Journal of Psychology, 33(1),34-38.

[14] Posner, M. I., \& Rothbart, M. K. (1998). Summary and commentary: Developing attentional skills. In J. E. Richards (Ed.), Cognitive neuroscience of attention: A developmental perspective. (pp. 317-323). Mahwah, NJ US: Lawrence Erlbaum Associates Publishers.

[15] Reddy, A.V.R. (1989). Problems of concern for many of the school going adolescents. Indian Psychological Review, 18 (1-4). 71-74.

[16] Shankar,K. and Pandey, K.(1985). Manual for Academic Anxiety Scale. Department of Education, Allahabad University.

[17] Sharma, M.C. (1971). Organizational Climate of schools and Academic Achievement. Indian Journal of Psychology and Education,2(1-2).

[18] Singh, S. \& Thukral, P. (2009). The role of anxiety in achievement. Journal of Exercise Science and Physiotherapy, Vol. 5 (2) 122-125.

[19] Singh, Y. G. (2009). Level of academic anxiety: Self confidence and their relation with academic achievement in secondary students. International Research Journal, Vol.1 (7), 12-13.

[20] Sinha, R. K. \& Bhargava, R. (1994). Manual for Socio-Emotional School Climate Inventory(SESCI) Ankur Psychology Agency,Lucknow.

[21] Tina \& Annayat, R.. (2014). Academic Anxiety of Adolescents in Relation to Their Vocational and Educational Interest. International Journal of Educational Research and Technology, 5(3),1-14.

[22] Tanzer, N. K. (1990). A dual-level approach to assessing social climates as perceived by students, teachers, and parents. German Journal of Psychology, 14(1), 13-20.

[23] Verma, B.P. \& C. K. Gupta. (1990). Influence of home environment on Children's' scholastic achievement Journal of Education and Psychology, 48(1-2), 17-21. 